\title{
最近の歯学
}

\section{7. 咀}

\section{睡眠時の咀嚼筋活動}

\section{東京医科歯科大学顎口腔総合研究施設咀嚼研究部門 中 村 嘉 男}

睡眠時の勗嚼筋活動の中で，歯科臨床に関係が深いも のに歯ぎしりがある。

ヒトの睡眠は, Dement and Kleitman (1957) ${ }^{1)}$ によ り，4つの時期に分けられている。脳波的に，第 I 期は 不規則な低振幅速波，第 II 期は睡眠紡鍾波と $\mathrm{K}$ 複合，第 III, IV 期は著明な徐波の出現により特徵づけられる。こ れらは徐波睡眠期にあたるが，この他に夢と関係づけら れる逆説睡眠期である第 I -REM 期があり，これは脳波 的には第 I 期に似るが，急速眠球運動 (Rapid eye movement, REM) の出現する時期である。歯ぎしりは, これ らいずれの睡眠期からも出現しらるが, 第III, IV 期に出 現することはまれで, 大多数は第川期に出現するという のが定説になっている2)。また REM の最中には決して 出現しないことが報告されている3)。

ヒトの骨格筋の覚醒時の持続的緊張は, 一般に入眠に つれて低下し，第 I -REM 期の出現とともに咀嚼筋を含 めて顔面頭頸部の筋緊張はさらに低下するが，四肢の屈 伸筋の緊張には低下が見られない4。 これは，ネコなど の動物では逆説睡眠期に四肢筋の緊張も著しく低下寸る のと対照的である5)。

睡眠時の咀嚼筋の反射活動はネコにおいて詳細に記載 され, 咬筋単シナプス反射は, 徐波睡眠期には安静覚醒 時に比較して軽度に減弱するに過ぎないが，逆説睡眠時 には明らかに持続性の減弱があり， REM の出現に一致 してさらに一過性の著しい減弱が起こることが明らかに されている ${ }^{6,7)}$ 。また, 開口反射の振舞いも, 咬筋単シナ プス反射の変動と同様である。

覚醒と睡眠に伴ら咀嚼筋反射の変化は, 脊髄の伸展な らびに屈曲反射と同一であるが，逆説睡眠時の脊髄反射 の持続性の反射低下に一致して運動ニューロンの興奮性 の持続的低下が見出され, これは運動ニューロンの膜電 位の持続的過分極によると推定されていた5)。また, REM に一致する一過性の脊髄反射減弱は, 筋紡鍾の一次終末 からの求心神経線維の中枢端のシナプス前終末の脱分極 （一次求心線維脱分極）によるシナプス前抑制に基づく ことを示す間接的証拠が得られていた ${ }^{5)}$ これらの推定
を実証するために，睡眠と覚醒期を通じて脊䯣運動ニュ 一ロンからの連続的細胞内記録が試みられてきたが，睡 眠時に脊髄運動ニューロンを安定に固定することが困難 なために成功していなかった。しかし, 最近, 無麻酔の ネコにおいて，覚醒と睡眠の各期をポリグラフ的に同定 すると同時に，これらの時期に脳幹ニューロンから連続 して安定な細胞内記録をおこなら技術が開発され，睡 眠時の閉口筋運動ニューロン活動の細胞内記録による解 析が括こなわれた ${ }^{8)}$ 。その結果, 逆説睡眠期には膜電位 レベルは徐波睡眠期よりも過分極に移行し, それととも に閾下シナプス活動が減少することが明らかにされ，逆 説睡眠期の持続的過分極は樹状突起上のシナプスを介す る抑制性シナプス後電位の増大あるいは興奮性シナプス 後電位の減少 (脱促通) によると結論された。また, REM に一致して, 閾下シナプス活動の増大を伴う一過 性の過分極電位の出現がみられ，このことから，以前か ら想定されていたシナプス前抑制に加えて, 運動ニュー ロン自体に抑制性シナプス後電位が出現していることが 判明した。したがって，閉口筋運動ニューロンには， REM に一致して，強力なシナプス後抑制がかかってい るとともに, 興奮性入力はシナプス前抑制により遮断さ れ，運動ニューロンの興奮性はもっとも低下しているこ とになる。この結果は, 歯ぎしりが REM の際中には決 して見られない事実を十分に説明するものである。すな わち，閉口筋運動ニューロンにたいするいかなる中枢性 および末梢性興奮性入力も, この強力な抑制にうちかっ て閉口筋運動ニューロンを興奮させることができないの であろら。

\section{文献}

1) Dement, W. C. \& Kleitman, N.: Cyclic variations in EEG during sleep and their relation to eye movements, body motility and dreaming. Electroenceph. clin. Neurophysiol., 9: 673-690, 1957.

2）新美良純，堀 忠雄 : 睡眠一その生理心理学. 東京, 1974, 培風館, 124ページ. 
3) Satoh, T. \& Harada, Y.: Electrophysiological study on tooth-grinding during sleep. Electroenceph. clin. Neurophysiol., 35: 267-275, 1973.

4) Jacobson, A., Kales, A., Lehmann, D. \& Hoedemaker, E. S.: Muscle tonus in human subjects during sleep and dreaming. Exp. Neurol., 10: 418-424, 1964.

5) Pompeiano, O.: The neurophysiological mechanisms of the postural and motor events during desynchronized sleep. Res. Publ. Ass. Nerv. Ment. Dis., 45: 351-423, 1967.

6) Chase, M. H., McGinty, D. J. \& Sterman, M. B.:
Cyclic variation in the amplitude of a brain stem reflex during sleep and wakefulness. Experientia, 24: 47-48, 1968.

7) Enomoto, T., Fukuoka, K., Imai, Y., Kako, M., Kaneko, Y., Mishimagi, M., Ono, A. \& Kubota, K.: Masseteric monosynaptic reflex in chronic cat. Jap. J. Physiol., 18: 169-178, 1968.

8) Nakamura, Y., Goldberg, L. J., Chandler, S. H. \& Chase, M. H.: Intracellular analysis of trigeminal motoneuron activity during sleep in the cat. Science, 199: 204-207, 1978. 